\title{
nature
}

\section{Prospect of US budget chaos}

\section{The US Supreme Court is now to have a say in this year's annual budget charade in Washington. Will it be better able than the Congress to count the cost outside the United States?}

THE annual tussle over the US federal budget between the US Congress and the administration will be more confused, even chaotic, this year than ever. That prospect has been on the cards for the past several months, ever since Congress passed the Gramm-Rudman Deficit Reduction Act, with the laudable objective of reducing the federal budget deficit to zero over the next five years, but by the curiously irrational process of delegating control of federal spending to a bunch of accountants at agencies such as the Office of Management and Budget if the Congress and the administration should fail to agree by deadlines specified in the act. That the Congress, which owes many of its powers over the federal budget to the eighteenth century doctrine of "no taxation without representation", should have been willing to delegate this central function as specified by the act was one of the big surprises of last year. That President Reagan should have been willing to let his hands be tied was an even greater puzzle, although the budget published last week suggests that he saw it as a chance to launch a budget free from spending of which he disapproves. The bombshell that has thrown all these calculations into disarray is the decision of a federal court last week that the Gramm-Rudman act is unconstitutional. The US Congress is to appeal to the Supreme Court, hoping that there will be some kind of decision by the early summer, in May or thereabouts. What this means is that the fierce debates about the budget that will occupy the next few months will be conducted in a vacuum. Political and economic chaos have supervened.

Last week's budget is hardly the place from which rational discussion could in any case have begun. Although the budget as a whole complies with the Gramm-Rudman act by planning to spend just less than the limit specified for the financial year beginning on 1 October, the President's package (see p.526) flies in the face of known congressional opinion. Defence spending is increased, most other forms of spending are reduced. Although basic research fares relatively well under the proposals, it is a striking measure of the skew of the package that direct support of research by civilian agencies should, under the plan, amount to only a half of what the Department of Defense would be spending on military research. In a normal year, the Congress would now embark on the familiar process of writing back into the budget items on which it considers that money should be spent; no doubt it would also repeat last year's process of cutting back the defence budget. The possibility that the GrammRudman act may be unconstitutional will give heart to those who think that this year will be no different from previous years. So the result is likely to be that, by the deadline of 15 August specified under the act, Congress's version of the budget will far exceed the limit of $\$ 144,000$ million. What will happen then?

\section{Devastation}

One of three things. If the Supreme Court finds the act to be constitutional, its provisions will come into effect, enforcing automatic reductions on rather less than a third of the total of planned expenditure. The effects could be devastating for some important programmes, those of agencies such as the National Science Foundation, for example. So financial chaos by the summer is one possible outcome. But the US Congress will not take well to such a prospect, and might decide that the best way of dealing with Gramm - Rudman is to get rid of it, in which case the whole episode will be seen in retrospect as having been another budgetary charade. That is the second outcome, little different from the third now in prospect that the Supreme Court will find the act unconstitutional, which will be a signal for a return to the budgetary process that has become familiar and notorious in the past decade. In theory, of course, the Congress might throw in the towel and swallow the substance of the administration's package for the sake of good government. But not in an election year.

\section{Chaos}

Where will it all end? And why, in any case, should it matter? The immediate effect of the annual confusion about the US budget is that the agencies depending on it for their spending authority do not know where they stand from one month to the next. The effects on the basic research agencies are to impede forward planning and thus the rational use of resources. That condition, now chronic, will be made worse this year. The effects of this uncertainty on the economy of the United States, and on its external monetary relations, may be even more serious. Only a few weeks ago, representatives of the five largest industrial economies meeting in London appear to have agreed that a concerted attempt to reduce money interest rates would make sense. But the capacity of the United States, which has a central influence on worldwide interest rates, to play a part in any such campaign is hamstrung by the federal deficit, which has to be financed by means of a competition for funds on the money markets of Wall Street. If it had seemed that Gramm-Rudman would have worked, it would at least have been possible to anticipate a less fierce competition. Now, with the whole issue clouded by uncertainty, the money-people will assume that the United States will remain a heavy borrower for at least the next two years. Economic growth will be held back in prosperous countries. Those, like Mexico, teetering on the edge of collapse because of a burden of foreign debt will look even more apprehensively at the future.

This is too high a price to pay for the US government's long-standing failure to agree on a mechanism for deciding how much the administration should be allowed to spend on what. The difficulty is only partly constitutional, although the convention that, in budgetary matters, the President proposes and the Congress disposes provides the opportunity for the familiar chaos. The more serious difficulties are political, stemming from the perennial conflicts between successive administrations and the Congress in questions such as the necessary cost of defence, the importance of social programmes of various kinds and the devotion of individual members of the Congress to local spending projects that may enhance their chances of re-election. What this year's budget cycle shows is that neither party to the exercise has an incentive to compromise with the other. The GrammRudman shotgun will clearly not do the trick. Maybe an arrangment that no member of the Congress should be paid a salary until the budget has been agreed would be more effective. 